\title{
Impact of biotic and abiotic factors on lac production and peoples' livelihood improvement in India-An overview
}

\section{S. Sarvade*}

College of Agriculture, Balaghat, Jawaharlal Nehru Krishi Vishwa Vidyalaya, Jabalpur Madhya Pradesh (482 004), India

R. K. Panse

College of Agriculture, Balaghat, Jawaharlal Nehru Krishi Vishwa Vidyalaya, Jabalpur, Madhya Pradesh (482 004), India

\section{S.K. Rajak}

College of Agriculture, Balaghat, Jawaharlal Nehru Krishi Vishwa Vidyalaya, Jabalpur, Madhya Pradesh (482 004), India

\section{B. Upadhyay}

College of Agriculture, Balaghat, Jawaharlal Nehru Krishi Vishwa Vidyalaya, Jabalpur, Madhya Pradesh (482 004), India

*Corresponding author. E-mail: somanath553@gmail.com

\begin{abstract}
:
In India, Madhya Pradesh is the third largest lac producing state after Chhattisgarh and Jharkhand, as they contribute 12,16 and $60 \%$, respectively in total country's lac production. Lac is produced in ten out of eleven agro-climatic zones of Madhya Pradesh. In total lac production of the state, Baisakhi (Butea monosperma, inoculated in OctoberNovember) crop contributes $76 \%$ followed by $19 \%$ by Katki (Butea monosperma, inoculated in June-July), 3\% by Aghani (Schleichera oleosa, inoculated in June-July) and $2 \%$ by Jethwi (Schleichera oleosa, inoculated in January-February). Ranchi was leading lac producing district followed by Simdega, Gumla, Khunti of Jharkhand and Seoni district of Madhya Pradesh. Increasing summer temperature up to $45^{\circ} \mathrm{C}$, the country's lac production was declined from 20,050 tons in 2003-04 to 16978 tons in 2014-15. In case of biotic factors, Tachardiaephagus tachardiae and Tetrastichus purpureus are the most abundant lac associated parasites and Eublemma amabilis and Pseudohypatopa pulverea are the most destructive key predators of lac insects. By combating these hindrances, lac cultivation generated an employment for 16-160 man days. Lac cultivation produces maximum gross return (Rs. 9,77,600) from 100 Kusum host plants, and the highest Benefit-Cost (6.80) ratio was recorded for Ber-kusumi (Ziziphus mauritiana- Schleichera oleosa) crop in Ranchi, Jharkhand. In this context, the study finds out obstacles in lac production of India and suggests some control measures to improve lac producing peoples' livelihood.
\end{abstract}

Keywords: Employment generation and income generation, Lac production, Laccifer lacca, parasites, predators.

\section{INTRODUCTION}

Lac is a natural, biodegradable, non-toxic, odourless, tasteless, non-injurious to health and hard resinous protective secretion of tiny lac insect, Kerria lacca (Kerr.). Coccus lacca Kerr, Chermes lacca Roxburgh, Carteria lacca Signoret, Lakshadia indica Mahdihassan, Tachardia lacca Chamberlin and Laccifer lacca Cockerell are synonyms of the Kerria lacca (Kerr.). The bulk of commercial lac is produced by Laccifer lacca (Kerr) insect in India, which belongs to the family Lacciferidae, super family Coccoidea, suborder Homoptera and order Hemiptera. Out of the nine genera and 99 species of lac-insects reported from all over the world; 2 genera and 26 species were found in our country, representing $26.3 \%$ of

\section{Article Info}

DOI:10.31018/jans.v10i3.1761

Received: May 28, 2018

Revised: July 10, 2018

Accepted: July 26, 2018

\section{How to Cite}

Sarvade, S. et al. (2018).

Impact of biotic and abiotic factors on lac production and peoples' livelihood improvement in India-An overview. Journal of Applied and Natural Science, 10(3): 894 - 904 the known lac-insect species diversity. But, much confusion prevails regarding their exact identity, and it is possible that many of them are only strains or varieties of $L$. lacca. National Lac Insect Germplasm Centre (NATLIGEC) of the Indian Institute of Natural Resins and Gums (IINRG) maintains 72 lines of lac-insects which include 14 cultivated, 35 natural populations, 22 cross bred/ in$\mathrm{bred} / \mathrm{selected}$ and one exotic line (IINRG, 2014). Some species found in India, also occur in other countries. L. albizziae is found in Ceylon, whereas, $L$. chinensis is the chief source of commercial lac in Thailand. The L. lacca is found in Burma, Cambodia, Laos, North Vietnam, China, Formosa, Indonesia, Philippines, Malaya, Pakistan, Nepal, Sikkim and Bhutan (Jaiswal and Sharma, 2011). On an average three hundred thousand insects 
Sarvade, S. et al. / J. Appl. \& Nat. Sci. 10 (3): 894 - 904 (2018)

produce $1 \mathrm{Kg}$ of lac resin. Two strains of the lac insect i.e. Rangeeni (Butea monosperma; Ziziphus xylopyra) and the Kusumi (Schleichera oleosa; Ziziphus mauritiana; Acacia catechu) were commonly recognized in India. Each strain completed its life cycle in six months, but the seasons of maturity differ considerably. Thus in the case of Rangeeni strain, Katki crop (Butea monosperma, inoculated in June-July) is harvested in OctoberNovember and Baisakhi crop (Butea monosper$m a$, inoculated in October-November) is obtained in June-July. Usually as a general practice, Baisakhi crop is harvested earlier in April or May as Ari i.e., in immature state of development. Similarly, in the case of Kusumi strain, Aghani crop (Schleichera oleosa, inoculated in June-July) is harvested in January-February and Jethwi crop (Schleichera oleosa, inoculated in JanuaryFebruary) is obtained in June-July. The present study was aimed to determine the impact of biotic and abiotic factors on the production of lac on different host plants.

Lac production: Lac insects can be nurtured on more than 400 plant species. Whereas, around hundred plants species have been recorded in India, on which lac insets grow for large scale lac production. The host plants for cultivation/raising of Rangeeni and Kusumi strains of lac insect is given in Table 1. Palas and ber were widely grown for raising Rangeeni crop, whereas kusum host plant for Kusumi crop. The list of lac host plants is given in Table 2 by accessing publications/ reports of researchers from different parts of India. Lac production of India was 16978 tonnes in 2014 -15, where $32.31 \%$ was contributed by Aghani, $26.36 \%$ by Jethwi, $23.57 \%$ by Baisakhi, and 17.76 $\%$ by Katki crop (Yogi et al., 2017). The Jharkhand state alone contributes around $60 \%$ in India's total lac production, so it is known as 'Lac State of India'. Chhattisgarh and Madhya Pradesh are the second and third largest lac producing states, respectively. Their contribution was 16 and $12 \%$ in India's lac production during 2013-14. Maharashtra contributes around $6 \%$ and also $6 \%$ by rest of the states of India (Fig. 1).

Bokaro, Dhanbad, Giridih, Khunti, Ranchi, Simdega and West Singhbhum are the lac producing districts of Jharkhand, whereas Seoni and Balaghat are the main lac producing districts of Madhya Pradesh. In case of Madhya Pradesh, lac is produced in ten out of its eleven agro-climatic zones. Jaitahari, Keshwahi, Kotma, Venkatnagar areas of Anuppur; Baihar, Katangi, Lalbarra, Lamta, Langi, Parashwada, Waraseoni areas of Balaghat; Damoa area of Chhindwara; Bazak, Bhanupur, Karanjia, Ramnagar, Rampur areas of Dindori; Bankhedi, Babai, Daggrai, Darawpadaw, Hapa, Jonahata, Kekra, Lokamti, Pipariya areas of Hoshangabad; Bichhia, Chabbi, Ghughari, Kalpi, Mahegaon, Mavai, Nainpur, Narainganj, Navas
-Bablia areas of Mandla; Chichli, Godarwara, Kalakhar, Kalyanpur, Nayakheda, Salechauka areas of Narshinghpur; Barghat, Ghansore, Kahani, Kanewara, Keolari, Khamaria, Khari areas of Seoni; Burhar, Jaitpur, Sohagpur areas of Shahdol are the main lac producing areas of different districts/clusters of Madhya Pradesh (Table 3).

Baisakhi strain contributes $76 \%$ followed by $19 \%$ by Katki, $3 \%$ by Aghani and $2 \%$ by Jethwi in total lac production of Madhya Pradesh (Fig. 3). Among these districts, Seoni contribute about $48 \%$ of the total stick lac production in Madhya Pradesh (Table 4 ) and it stands at $5^{\text {th }}$ position in India after Ranchi, Simdega, Gumla and Khunti districts of Jharkhand (Fig. 2). The majority of the lac producing districts are predominantly tribal, have high rainfall $(100$ to $140 \mathrm{~cm}$ ) with soil varying from shallow medium black, medium deep black to mixed red and black (Yogi et al., 2017). Among all the lac producing districts of Madhya Pradesh, only five districts i.e. Balaghat, Chhindwada, Hoshangabad, Mandla and Seoni have market places. Whereas, Indore and Hoshangabad only have lac processing units (Table 5).

Lac production in India from the year 2003-04 to 2014-15 showed reducing trend. Lowest production recorded in the year of 2010-11 and highest production in 2013-014. In case of Madhya Pradesh, lowest lac production was also reported in 2010-11, whereas highest in 2007-8 (Fig. 4). This may be due to fluctuations in climatic factors, however the impact of climatic parameters on lac production was undistinguishable. Some researchers reported that temperature is the most important climatic factor affecting lac production (Mishra et al., 1999a, 1999b; Bhagat and Mishra, 2002; Sharma, 2007; Thomas, 2010), whereas Pal et al. (2009; 2011) reported that the high summer temperature is the main cause of annual national lac production.

Factors affecting lac insects: Lac crop is vulnerable to both biotic and abiotic stress conditions (Bhagat and Mishra, 2002; Jaiswal et al., 2008). Environment of an agro-ecosystem is largely governed by interactions between abiotic and biotic components. The abiotic stress factors alter the effects of biotic stresses and are most harmful when occur in combination (Mittler, 2006).

Abiotic: Climate of India has undergone significant changes showing increasing trends in annual temperature with an average of $0.56^{\circ} \mathrm{C}$ rise over last 100 years (IPCC, 2007; Rao et al., 2009; Anonymous, 2010). The production of lac is greatly influenced by the climatic factors, like temperature, rainfall, humidity, wind etc, (Nicholson, 1925; Bhagat and Mishra, 2002). The temperature is the most important climatic factor affecting lac production (Mishra et al., 1999a, 1999b; Bhagat and Mishra, 2002; Sharma, 2007; Thomas, 2010). The annual national lac production declined from 
Table 1. Host plants for the cultivation of two lac insect strains in India.

\begin{tabular}{ll}
\hline Strain & Host plants \\
\hline Rangeeni & Palas/dhak (Butea monosperma), Ber (Ziziphus mauritiana), Ghont/kat-ber (Ziziphus xy- \\
& lopyra), Porho/khunia/jahrphali (Ficus cunia), Barh/bargad/banyan (Ficus benghalensis), \\
& Peepal (Ficus religiosa), Arhar (Cajanus cajan), Tapria siris (Albizia lucida), Panjan/sandan \\
& (Ougeinia oojeinensis), khair (Acacia catechu) for ari, Pansaura (Grewia serrulata DC.) \\
Kusumi & Kusum (Schleichera oleosa), Khair (Acacia catechu), Ber (Ziziphus mauritiana)
\end{tabular}

(Source: Chattopadhyay, 2011; Yogi et al., 2017)

Table 2. Host plants for cultivation of lac insects in different states of India.

\begin{tabular}{|c|c|c|}
\hline State & Important lac hosts reported & Source \\
\hline All parts of India & $\begin{array}{l}\text { Butea monosperma, Ficus religiosa, F. glomerata, F. } \\
\text { benghalensis, F. infectoria }\end{array}$ & $\begin{array}{l}\text { Sharma et al., 1997; Shrivastava, } \\
\text { 2007; Anonymous, 2010; Chatto- } \\
\text { padhyay, 2011; Paul et al. } 2013\end{array}$ \\
\hline West Bengal & $\begin{array}{l}\text { Ziziphus mauritiana, B. monosperma, Ficus spp., } \\
\text { Samanea (Albizia) saman }\end{array}$ & $\begin{array}{l}\text { Sharma et al., 2006; Anonymous, } \\
\text { 2010; Chattopadhyay, } 2011\end{array}$ \\
\hline Punjab & Zizyphus mauritiana, A. nilotica, Ficus spp. & $\begin{array}{l}\text { Sharma et al., 2006; Anonymous, } \\
\text { 2010; Chattopadhyay, } 2011\end{array}$ \\
\hline Jharkhand & $\begin{array}{l}\text { Butea monosperma, Schleichera oleosa, Ziziphus } \\
\text { mauritiana, Flemingia semialata Roxb., Albizia lucida, } \\
\text { Acacia catechu, Croton oblongifolius, Ficus spp., } \\
\text { Protium serratum, Litchi chinensis, Mangifera indica, } \\
\text { Santalum album, Thea chinensis }\end{array}$ & $\begin{array}{l}\text { Sharma et al., 2006; Anonymous, } \\
\text { 2010; Chattopadhyay, 2011; Paul } \\
\text { et al., 2013; Meena et al., 2014; } \\
\text { IINRG, } 2014\end{array}$ \\
\hline Chhattisgarh & $\begin{array}{l}\text { Z. mauritiana, Z. xylopyra, Acacia catechu, B. mono- } \\
\text { sperma, S. oleosa }\end{array}$ & $\begin{array}{l}\text { Sharma et al., 2006; Anonymous, } \\
\text { 2010; Chattopadhyay, } 2011\end{array}$ \\
\hline $\begin{array}{l}\text { Madhya } \\
\text { Pradesh }\end{array}$ & $\begin{array}{l}\text { Schleichera oleosa, Ziziphus jujuba, Z. mauritiana } \\
\text { (Lamb.) }\end{array}$ & $\begin{array}{l}\text { Anonymous, 2010; Chattopadh- } \\
\text { yay, 2011; Shah et al., 2014; }\end{array}$ \\
\hline Uttar Pradesh & Z. zylopyra, A. nilotica, B. monosperma, Z.mauritiana & $\begin{array}{l}\text { Sharma et al., 2006; Anonymous, } \\
\text { 2010; Chattopadhyay, } 2011\end{array}$ \\
\hline Orissa & Schleichera oleosa, 2 & $\begin{array}{l}\text { Sharma et al., 2006; Anonymous, } \\
\text { 2010; Chattopadhyay, } 2011\end{array}$ \\
\hline Karnataka & $\begin{array}{l}\text { Schleichera oleosa, Acacia spp., Ficus spp., Shorea } \\
\text { talura }\end{array}$ & $\begin{array}{l}\text { Sharma et al., 2006; Anonymous, } \\
\text { 2010; Chattopadhyay, } 2011\end{array}$ \\
\hline Tamil Nadu & $\begin{array}{l}\text { Schleichera oleosa, Shorea talura, A. nilotica, } B . \\
\text { monosperma, Z. mauritiana }\end{array}$ & $\begin{array}{l}\text { Sharma et al., 2006; Anonymous, } \\
\text { 2010; Chattopadhyay, } 2011\end{array}$ \\
\hline Rajasthan & $\begin{array}{l}\text { Acacia nilotica, B. monosperma, Ficus spp., Z. mauri- } \\
\text { tiana, Albizia saman }\end{array}$ & $\begin{array}{l}\text { Sharma et al., 2006; Paul et al., } \\
\text { 2013; IINRG, } 2014\end{array}$ \\
\hline Gujarat & $\begin{array}{l}\text { Acacia nilotica, A. catechu, B. monosperma, Z. mau- } \\
\text { ritiana, Albizia saman }\end{array}$ & $\begin{array}{l}\text { Sharma et al., 2006; Paul et al., } \\
\text { 2013; IINRG, } 2014\end{array}$ \\
\hline Assam & $\begin{array}{l}\text { Ficus cunia, Ficus rumphii, Cajanus cajan, Albizia } \\
\text { lucida, Grewia spp., Leea spp., Moghania macrophyl- } \\
\text { la, Kydia calycina; Flemingia macrophylla }\end{array}$ & $\begin{array}{l}\text { Sharma et al., 2006; Chattopadh- } \\
\text { yay, } 2011\end{array}$ \\
\hline Maharashtra & $\begin{array}{l}\text { Acacia catechu, A. nilotica, B. monosperma, S. ole- } \\
\text { osa, Z. mauritiana }\end{array}$ & Sharma et al., 2006; \\
\hline Andhra Pradesh & $\begin{array}{l}\text { B. monosperma, Albizia saman, Peltophorum ferru- } \\
\text { genium }\end{array}$ & Sharma et al., 2006; \\
\hline
\end{tabular}

20,050 tons in 2003-04 (Pal et al., 2009) to 16,978 tons in 2014- 15 (Yogi et al., 2017) due to high summer temperatures (Pal et al., 2009). Meteorological factors play an important role in the population fluctuation of sucking insect pests (Gogoi and Dutta, 2000; Murugan and Uthamasamy, 2001; Panickar and Patel, 2001). High rainfall during the month of July influences lac insect settlement (Patel et al., 1997). Changes in rainfall patterns, frequent droughts and floods, increased intensity and frequency of cold waves, outbreaks of insect pests and diseases area affecting many biological systems profoundly (IPCC, 2007) and lac sub-sector is also affected equally.

Biotic: The lac insect during its whole life cycle spends only a few hours of active mobility and after that spends a complete sedentary life. Hence they are prone to be attacked by many insect predators and parasitoids, causing substantial damage to the lac crop qualitatively and quantitatively (Singh et al., 2011a). The predators of lac insect include both vertebrate and invertebrate species (Mohanta et al., 2014; Shah et al., 2015).

Vertebrate: The important vertebrate enemies are squirrels and rats. The damage caused by those enemies can be as serious as $50 \%$ brood sticks were damaged by them. Squirrels are active during the day time and the damage by them is more common under forest condition. Rats are active in night time and the damage usually occurs near about the villages.

Invertebrates: It has been estimated that on an 
Table 3. Major lac producing areas and districts of Madhya Pradesh, India.

\begin{tabular}{lll}
\hline S. N. & Name of district & Major lac producing areas \\
\hline 1 & Anuppur & Jaitahari, Keshwahi, Kotma, Venkatnagar \\
2 & Balaghat & Baihar, Katangi, Lalbarra, Lamta, Langi, Parashwada, Waraseoni \\
3 & Chhindawada & Damoa \\
4 & Dindori & Bazak, Bhanupur, Karanjia, Ramnagar, Rampur \\
5 & Hosangabad & Bankhedi, Babai, Daggrai, Darawpadaw, Hapa, Jonahata, Kekra, Lokamti,Pipariya \\
6 & Mandla & Bichhia, Chabbi, Ghughari, Kalpi, Mahegaon, Mavai, Nainpur, Narainganj, Navas- \\
& & Bablia \\
7 & Narshinghpur & Chichli, Godarwara, Kalakhar, Kalyanpur, Nayakheda, Salechauka \\
8 & Seoni & Barghat, Ghansore, Kahani, Kanewara, Keolari, Khamaria, Khari \\
9 & Shahdol & Burhar, Jaitpur, Sohagpur \\
\hline
\end{tabular}

(Source: Yogi et al., 2017)

Table 4. Stick lac production (in tons) scenario in main lac producing district of Madhya Pradesh 2013-14, India.

\begin{tabular}{llllll}
\hline \multirow{2}{*}{$\begin{array}{l}\text { Name of } \\
\text { district }\end{array}$} & \multicolumn{2}{l}{ Name of lac crops } & & Total production \\
\cline { 2 - 5 } & Baisakhi & Jethwi & Katki & Aghani & \\
\hline Annuppur and Shahdol & 5 & 2 & 2 & 1 & 10 \\
Balaghat & 700 & 5 & 180 & 5 & 890 \\
Chhindwada & 15 & 6 & 7 & 8 & 36 \\
Dindori & 45 & 8 & 7 & 5 & 65 \\
Hoshangabad & 15 & 8 & 5 & 5 & 33 \\
Mandla & 50 & 2 & 40 & 15 & 107 \\
Narsinghpur & 10 & 2 & 2 & 2 & 16 \\
Seoni & 1000 & 5 & 170 & 10 & 1185 \\
Others & 70 & 10 & 55 & 20 & 155 \\
Total & $\mathbf{1 9 1 0}$ & $\mathbf{4 8}$ & $\mathbf{4 6 8}$ & $\mathbf{7 1}$ & $\mathbf{2 4 9 7}$ \\
\hline
\end{tabular}

(Source: Yogi et al., 2017)

Table 5. Major lac markets and processing centres in Madhya Pradesh, India.

\begin{tabular}{|c|c|c|c|c|}
\hline Sr. No. & District & Market place & Processing centre & $\begin{array}{l}\text { Quantity processed } \\
\text { (tons) in 2013-14 }\end{array}$ \\
\hline 1 & Balaghat & $\begin{array}{l}\text { Waraseoni, Katangi, Lal- } \\
\text { barra and Langi }\end{array}$ & - & \\
\hline 2 & Chhindawada & Damoh & - & \\
\hline 3 & Hoshangabad & Pipariya & - & \\
\hline 4 & Mandla & Bichhia and Nainpur & - & \\
\hline 5 & Seoni & Barghat, Keolari and Khari & - & \\
\hline \multirow[t]{2}{*}{6} & - & - & $\begin{array}{l}\text { Indore: - For: Seedlac, } \\
\text { Bleached lac) }\end{array}$ & \\
\hline & & & $\begin{array}{l}\text { Hoshangabad } \\
\text { (Bankedhi):- For Seed- } \\
\text { lac }\end{array}$ & 18 \\
\hline
\end{tabular}

(Source: Yogi et al., 2017)

average, up to $30-40 \%$ of the lac cells are destroyed by invertebrate enemies. The enemy attack can be as serious as it results in failure of crop. These are two kinds of enemy insects:

Parasites: All the parasites so far reported on lac are insects. Parasite accounts for a damage of 5$10 \%$. Till date about 19 parasites of lac insect have been recorded in India. The list of predators of lac insects are given in Table 6. Tachardiaephagus tachardiae and Tetrastichus purpureus were the most abundant lac associated parasites (Sharma, 2017). They lay eggs in lac cells, grubs (larvae) hatching out and feed on the lac insect.

Sharma et al., (2007) studied super parasitism in $K$. lacca, its implications on fecundity and resin producing efficiency. Parasitoids of lac insect were affect adversely on the resin yield and the fecundity of the insects, particularly during rainy seasons. The average reduction in resin production due to parasitism varied between 17.25-39.80 $\%$ in Rangeeni and 25.24-37.91 \% in Kusmi. According to Narayanan (1962) super parasitism can occur but typically one parasite larva occurs in single scale. The parasitoids have life cycle of about one month, compared to 4-9 months for $K$. lacca. Tachardiaephagus tachardiae, Aprostocetus purpureus, Coccophagus tschirchii have 10-12 generation on commercial lac in a year, compared to 9 generation for Paraechthrodryinus clavicornis Cameron, an encyrtid, that can be either a primary or secondary parasitoids. $T$. tachardiae and $A$. purpureus are the most abundant lac associated parasitoids belongs to the order hymenoptera (Chattopadhyay, 2011). 
Sarvade, S. et al. / J. Appl. \& Nat. Sci. 10 (3): 894 - 904 (2018)

Table 6. List of lac insect parasites with their family.

\begin{tabular}{lll}
\hline $\mathbf{S}$. & Name of the parasites & Family \\
$\mathbf{N}$. & & \\
\hline 1 & Anicetus dodonia & Encyrtidae \\
2 & Atropates hautefeuille & Encyrtidae \\
3 & Aphrastobracon flavipennis & Encyrtidae \\
4 & Bracon greeni & Encyrtidae \\
5 & Campyloneurus indicus & Encyrtidae \\
6 & Coccophaqus tchirchii & Aphelinidae \\
7 & Erencyrtus dewitzi & Encyrtidae \\
8 & Eupelmus tachardiae & Eupelmidae \\
9 & Eurymyiocnema aphelinoides & Aphelinidae \\
10 & Lyka lacca & Encyrtidae \\
11 & Marietta javensis & Aphelinidae \\
12 & Parageniaspis indicus & Encyrtidae \\
13 & Parechthrodryinus clavicornis & Encyrtidae \\
14 & Protyndarichus submettalicus & Encyrtidae \\
15 & Tachardiaephagus tachardiae & Encyrtidae \\
16 & Teachardiobius nigricans & Encyrtidae \\
17 & Aprostocetus(Tetrastichus) purpureus & Eulophidae \\
\hline
\end{tabular}

(Source: Sharma, 2017)
Table 7. List of lac insect predators with their family.

\begin{tabular}{lll}
\hline S.N. & Name of predator & Family \\
\hline 1 & Eublemma amabilis & Noctuidae \\
2 & E. coccidiphaga & Noctuidae \\
3 & E. cretacea & Noctuidae \\
4 & E. scitula & Noctuidae \\
5 & Pseudohypatopa pulverea & Blastobasidae \\
6 & Catablemma sumbavensis & Blastobasidae \\
7 & Cryptoblabes ephestialis & Blastobasidae \\
8 & Phroderces falcatella & Cosmoptery- \\
& & gidae \\
9 & Lacciferophaga yunnanea & Momphidae \\
10 & Chrysopa madestes Neuroptera & Chrysopidae \\
11 & C. lacciperda & Chrysopidae \\
12 & Berginus maindroni & Mycetopha- \\
& & gidae \\
13 & Silvanus iyeri & Cucujidae \\
14 & Tribolium ferrugineum & Tenebrionidae \\
15 & Phyllodromia humbertiana & Blattellidae \\
16 & Ischonoptera fulvastrata & Blattellidae \\
\hline
\end{tabular}

(Source: Mohanta et. al., 2014; Sharma, 2017)

Table 8. Employment generation from lac cultivation in untrained lac-growers and trained lac-growers.

\begin{tabular}{|c|c|c|c|c|}
\hline \multirow[t]{2}{*}{ Particulars' } & Palas (50 hosts) & Beri (50 hosts) & Kusumi(10 hosts) & Total M.D. \\
\hline & \multicolumn{4}{|c|}{ Man-days } \\
\hline $\begin{array}{l}\text { Human labour (Untrained lac- } \\
\text { growers) }\end{array}$ & 24.8 & 47.2 & 41.2 & 113.2 \\
\hline (H.L.)Trained lac-growers & 34.2 & 69.5 & 50.0 & 153.7 \\
\hline
\end{tabular}

(Source: Pal, 2009)

Table 9. Employment generation from lac cultivation.

\begin{tabular}{llccc}
\hline Particulars' & Palas (100 hosts) & Ber-Rangeeni (100) & Ber-Kusumi (100) & Kusum (40 hosts) \\
\cline { 2 - 5 } & \multicolumn{4}{c}{ Man-days } \\
\hline Male & $28-55$ & $39-67$ & 87 & $108-147$ \\
Female & $17-35$ & $77-110$ & 58 & $85-160$ \\
\hline
\end{tabular}

(Source: Jaiswal et al., 2011; 2013)

Table 10. Economic benefits from lac cultivation.

\begin{tabular}{lllll}
\hline Particulars' & Kususm (100) & Palas (100) & Ber-Rangeeni (100) & Ber-kusumi (40) \\
\hline Gross return (Rs) & $9,77,600$ & $1,25,000$ & $4,20,000$ & $8,55,000$ \\
Cost (Rs) & $1,87,954$ & 29,399 & $97,471.5$ & $1,09,642$ \\
Net return (Rs) & $7,89,646$ & 95,601 & $3,22,529$ & $7,45,358$ \\
B:C ratio & 4.20 & 3.25 & 3.31 & 6.80 \\
\hline
\end{tabular}

(Source: Jaiswal et al., 2011; 2013)

Table 11. Income generation from lac cultivation in untrained lac-growers and trained lac-growers.

\begin{tabular}{lllll}
\hline Host Plant & Particular & $\begin{array}{l}\text { Untrained Lac- } \\
\text { growers (Rs.) }\end{array}$ & $\begin{array}{l}\text { Trained Lac- } \\
\text { growers (Rs.) }\end{array}$ & $\begin{array}{l}\text { Increase by trained lac } \\
\text {-growers (\%) }\end{array}$ \\
\hline Palas(50) & Cost of cultivation & 2566 & 3533 & 38 \\
& Net return & 4886 & 8169 & 67 \\
& Input-output ratio & 2.90 & 3.31 & 14 \\
Ber (50) & Cost of cultivation & 4674 & 7961 & 70 \\
& Net return & 9771 & 20914 & 114 \\
& Input-output ratio & 3.09 & 3.63 & 17 \\
Kusum(10) & Cost of cultivation & 6881 & 11042 & 60 \\
& Net return & 16284 & 33128 & 103 \\
& Input-output ratio & 3.37 & 4.0 & 19 \\
\hline
\end{tabular}

(Source: Pal et al., 2009)

Predators: The predators on the other hand, are more serious and may cause damage to the cells in a crop up to $30-35 \%$. About 20 predators have been reported from different parts of the country, which include vertebrates as well as insects. The list of predators of lac insects is given in Table 7. Eublemma amabilis and Pseudohypatopa pulverea were the most destructive key pests of lac in- 
Sarvade, S. et al. / J. Appl. \& Nat. Sci. 10 (3): 894 - 904 (2018)

Table 12. Comparative study of net income derived from farm activities, non-farm activities and lac activities in Purulia district of West Bengal. (Source: Mandal and Sarkhel, 2014)

\begin{tabular}{lllll}
\hline Farm Size Group & $\begin{array}{l}\text { Net Income } \\
\text { From Farm Activities } \\
\text { (In Rs.) }\end{array}$ & $\begin{array}{l}\text { Net Income } \\
\text { From Non-Farm } \\
\text { Activities (In Rs.) }\end{array}$ & $\begin{array}{l}\text { Net Income } \\
\text { From Lac Activi- } \\
\text { ties (In Rs.) }\end{array}$ & $\begin{array}{l}\text { Total } \\
\text { Income } \\
\text { (In Rs.) }\end{array}$ \\
\hline Marginal & $3,78,282.50$ & $4,20,000$ & $9,60,158.50$ & $17,58,441.00$ \\
& $(21.51 \%)$ & $(23.88 \%)$ & $(54.61 \%)$ & \\
Small & $8,32,385.00$ & $1,71,000.00$ & $9,54,597.30$ & $19,57,982.30$ \\
& $(42.51 \%)$ & $(8.73 \%)$ & $(48.76 \%)$ & \\
Medium & $8,92,682.50$ & $1,43,000$ & $12,95,706.60$ & $23,31,389.10$ \\
& $(38.29 \%)$ & $(8.73 \%)$ & $(55.58 \%)$ & \\
Total & $21,03,350.00$ & $7,34,000.00$ & $32,10,462.40$ & $60,47,812.40$ \\
& $(38.29 \%)$ & $(12.14 \%)$ & $(53.08 \%)$ & \\
\hline
\end{tabular}

(Figures within the parentheses indicate percentage to total income.)

sects but their incidence may vary from season to season, place to place and crop to crop (Chattopadhyay, 2011; Khopragade et al., 2012; Sharma, 2017).

Eublemma amabilis Moore (Lepidoptera: Noctuidae): It is widely distributed in all major lac growing regions of the country and is considered to be the most destructive predator of lac insect. The moth lays greyish white, round eggs, depressed in the centre and with beautiful sculpturing of the chorion. Eggs were laid singly. The first instar larva measures 0.51 to $0.54 \mathrm{~mm}$ in length. The newly hatched larva gets either through one of the openings or by tunnelling a hole through the encrustation. The attacked lac cell becomes hollow containing pink coloured discs of excreta and can be easily differentiated from the healthy cells. A single larva can destroy 40-60 lac insect cells during various instars before pupation.

Rahman et al. (2009) reported that the single larva of $E$. amabilis damages 42-50 mature lac cells before pupation and causes more injury to the Kartki crop than to the Baishakhi crop.

Pseudohypatopa pulverea Meyr (Lepidoptera: Blastobasidae): This predator is also widely distributed and found in all the lac growing areas of the country. Adult moth is blackish in colour and smaller in size than E. amabilis. Predator feeds on the live and dead lac insects and it found in large numbers in stored lac as well. Eggs of $P$. pulverea

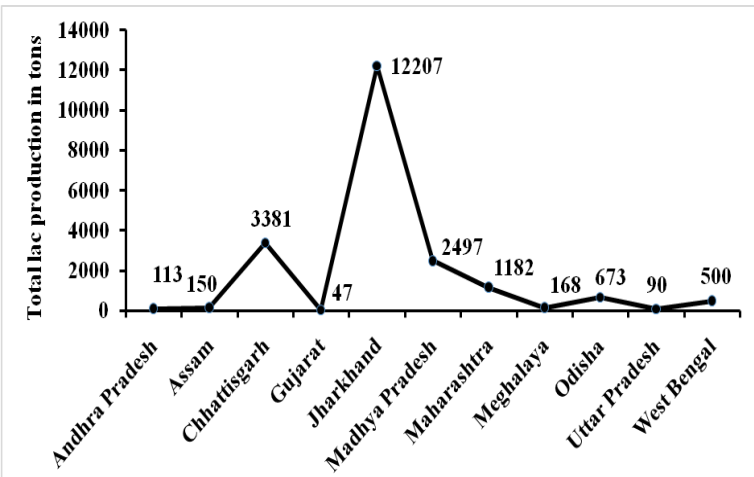

Fig. 1. Status of lead lac producing states of India during 2013-14 (in tons) (Source: Yogi et al., 2017). are oval in shape and laid singly on the lac insect. Newly hatched larva is about $1.35 \mathrm{~mm}$ in length. It feeds on the lac larvae and spins a loose web. A single predator has a capability to destroy 45 to 50 mature lac cells. It is considered to be very important, as it inflicts damage to the developing lac crop and also responsible for qualitative and quantitative deterioration of the stored lac.

Two lepidoptera predators i.e. Eublemma ambilis and Pseudohypatopa pulverea causes 30-40\% damage to lac crop (Glover, 1937; Mishra, 2002; Jaiswal et al., 2008; Singh et al., 2009). The monophagous predator ( $E$. amabilis) of lac insect, causes damage to lac crop up to 20 to $25 \%$ (Narayanan, 1962).

Chrysopa spp. (Neuroptera: Chrysopidae): Larvae of the predator considered to be sporadic pest and prey upon various stages of the lac insect. Females lay eggs either on the lac encrustation, on leaves or any part of the host trees. Larvae emerge out from the egg shell with the aid of an "egg buster", climb down the stalk and start feeding immediately on the insect by inserting its long pair of mandibles.

The sporadic neuropteran (Chrysopa spp) is the most ubiquitous predator of the lac insect causing considerable loss, especially in the winter crops of Kusmi. A severe infestation by Chrysopa spp may lead to the loss of whole winter season crop, if not managed properly (Singh et al., 2011b). The first,

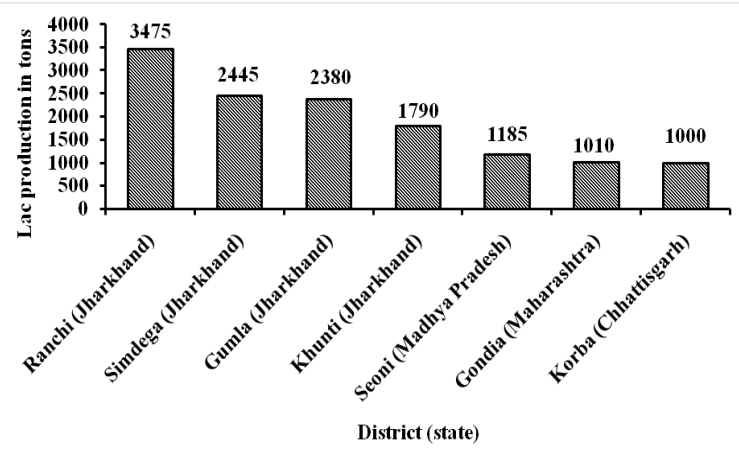

Fig. 2. First seven high lac producing districts in different states of India (2013-14)(Source: Yogi et al., 2017) 
Sarvade, S. et al. / J. Appl. \& Nat. Sci. 10 (3): 894 - 904 (2018)

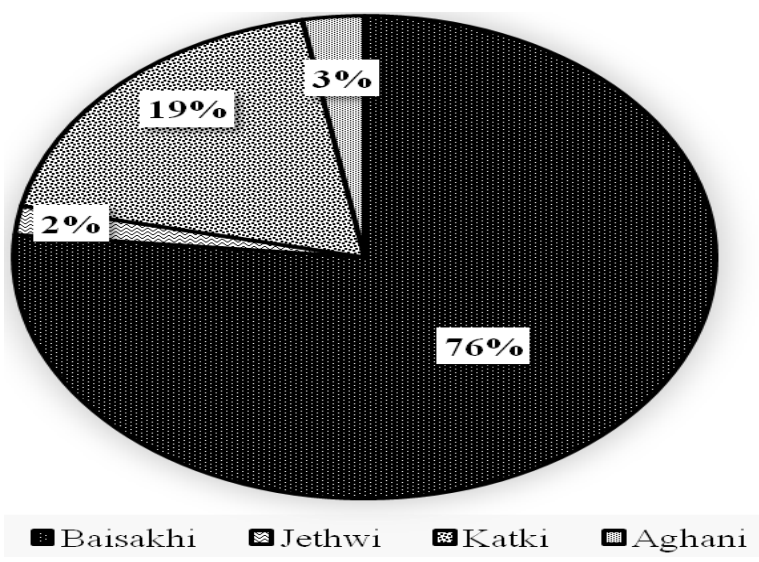

Fig. 3. Strain wise contribution (\%) in total lac production (2013-14). (Source: Yogi et al., 2017).

second and third instar larvae of Chrysopa madestes can consume 20, 24 and 74 mature females of lac insect per day, respectively (Mehra, 1965, 1966).

Microbial flora associated with lac insects: Two types of micro-flora viz. bacteria and fungi are associated with the lac insects. Bacteria act as a lac hosts and they could be symbiotic or pathogenic. Besides insect enemies, lac crop yield suffers significantly due to other biotic agents particularly fungi. Fungal infection in lac culture causes severe losses of lac yield by i) Killing the lac insects through inhibiting respiration, ii) Hindering mating process, iii) Blocking larval emergence, iv) Affecting lac host efficiency.

Lac culture during rainy season is prone to fungal attack particularly when grown on Ber (Ziziphus mauritiana), Kusum (Schleichera oleosa). It may be due to their steady and spreading crown. Three species of fungi belonging to family Eurotiaceae and Aspergillaceae viz. Aspergillus awamori, A. terricola and Penicillium citrinum were reported to cause maximum loss in lac production. $A$. awamori and $P$. citrinum are black and greenish in colour, respectively. They were observed to make a continuous cover on lac insect and thereby blocking their breathing pores which leads to mortality of lac insects. A pathogenic fungus, Pythium spp. causes a heavy mortality of lac larvae which fail to enclose and dead in clusters within the female resinous cells.

\section{Prevention and control of insect enemies}

Preventive measures: Brood lac, free from parasite and predator should be used for inoculation. Self-inoculation of lac crops should be avoided as far as possible. Inoculated brood bundles should be kept on the host tree for a minimum period only. Phunki (empty brood lac sticks) should be removed from the inoculated trees within $2-3$ weeks. All the collected lac from the tree and all phunki brood lac (after use as brood lac) should be scraped or fumigated at once. Cultivation of Kusmi strain of lac should be avoided in predominantly Rangeeni area and vice versa.

Mechanical control: Use of 60 synthetic mesh net (brood bag) to enclose brood lac for inoculation purposes. It can reduce infestation of enemy insects. The emerging lac larvae easily crawl out from the minute pores of the net and settle on the twigs of the lac host plants. Whereas the emerging adult predator enemies cannot move out of the brood bags and get entrapped within the net (Malhotra, 1983). This can check the egg laying by the predator moths on the new crop. Chrysopa spp. attacking Kusmi crop raised on Kusum ( $S$. oleosa) during the months of August and September can be trapped by placing a light trap.

Cultural and physical management: Keeping the brood sticks inside a 60 mesh nylon net bag during inoculation traps parasitoids and predators, while allowing only lac crawlers to come out for settlement on new shoots (Malhotra, 1983). Khobragade et al., (2012) while conducting a farmer participatory trial on the predator of $K$. lacca management revealed two options for the man-

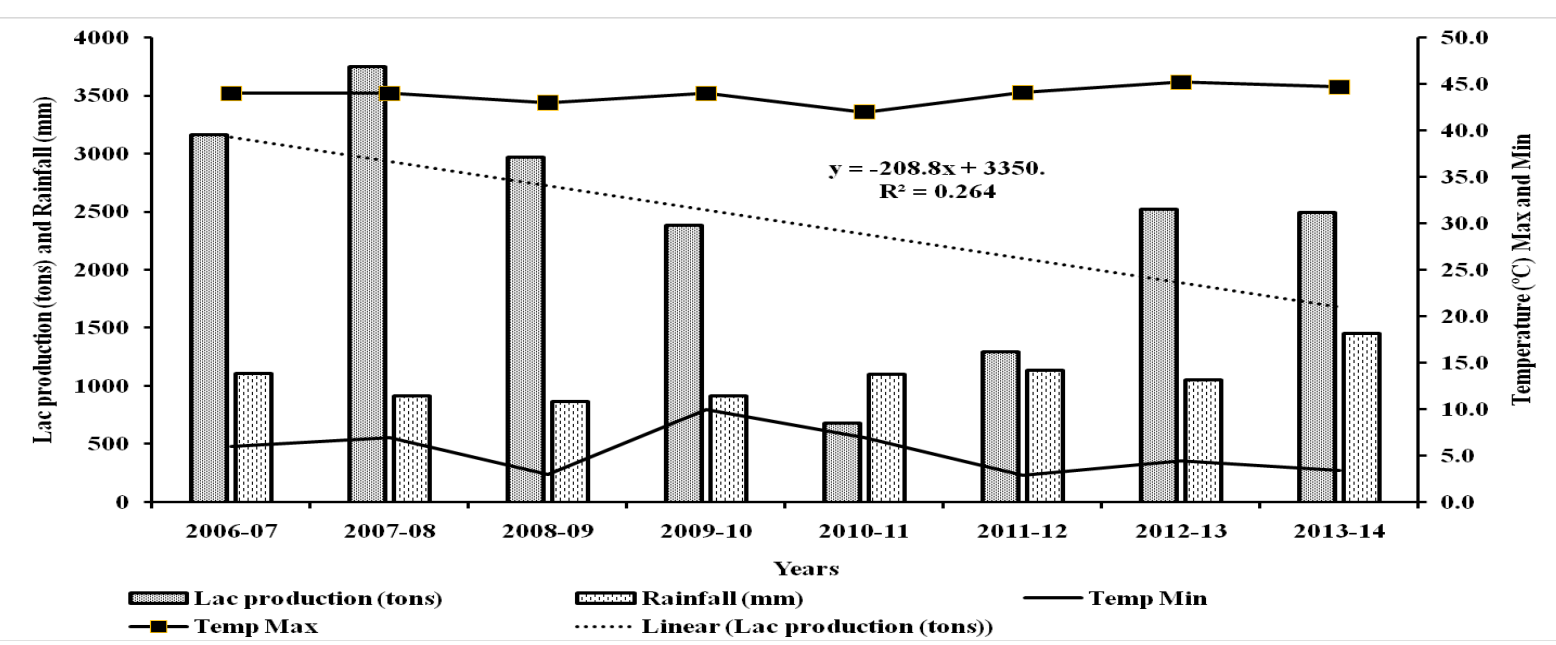

Fig. 4. Lac production with relation to changing climatic conditions. (Source: Yogi et al., 2017; Pal, 2015; Anonymous, 2006, 2007, 2008, 2009, 2010, 2011, 2012 and 2013) 
agement of $E$. amabilis. Lac growers with poor investment capacity and those having their $B$. monosperma tree on the hilly and water scarce areas may opt for 60 mesh nylon net pouch for the management of $E$. amabilis in the lac crop. Whereas those with better financial status and the trees in plain area and sufficient water can opt for a combination of 60 mesh nylon pouches. Planting of Cassia occidentalis L. (Family: Leguminosae), a medicinal plant, on the periphery of a plot having F. macrophylla bushes resulted in significant reduction in the population of the two Lepidopteran lac insect predators viz. E. amabilis and $P$. pulverea. It resulted that the significant increase in brood lac yield.

Chemical control: Application of $0.05 \%$ Quinalphos at 30-35 days of the crop has been identified as the most effective dose of insecticide without any adverse effect on the economic attributes of the lac insect (Mishra et al., 1996).

Gupta and Bhattacharya (2007) evaluated the toxicity of naturalyte compound against Spilarctia oblique and reported that Spinosad was more active after $48 \mathrm{hr}$ of treatment. Fipronil $(0.005$ and $0.01 \%)$ and Indoxacarb $(0.02 \%)$ were equally effective as they cause cent per cent larval mortality within $24 \mathrm{hr}$ of treatment with both mode of application (topical application and residual exposure). Ethofenprox $(0.02 \%)$ was most suitable for protecting lac crop at critical stages against $C$. madestes under field conditions (Jaiswal et al., 2007). Toxicity of ethofenprox against first instar larvae of $C$. carnea has been reported by Toda and Kashio (1997).

Microbial control: Use of bio- pesticide such as Bacillus thuringiensis at 30-35 days stage of crop was found to be effective microbial control measure for important enemy insects of lac. The suppression of lac predator was due to higher incidence of Trichogramma chilonis Ishi which is an egg parasitoid of Lepidopteran insects (Bhattacharaya et al., 2006).

Biological control: Two ants' viz. Camponotus compresus and solenopsis geminate rufa were the most important and promising for biological control of predator enemies of lac. Egg parasitoids viz. Trichogramma pretiosum, T. chilonis, T. poliae, Trichogrammatoidea bactrae and Telenomus remus have been found to be effective in management of lac predators. E. amabilis can be controlled by using natural enemies such as Componotus compressus and Solenopsis geminata (Rahman et al., 2009). Bhattacharya et al. (2006) carried out the field evaluation trail for management of $E$. amabilis with three species of the egg parasitoids ( $T$. achaea, $T$. exigum and $T$. ostrinae). They revealed significant suppression of $E$. amabilis over the control by releasing 75 egg parasitoids per plant in Kusmi and Rangeeni. They are also equally affective to suppress the popula- tion of $E$. amabilis on lac crop raised on the bushy host plant, F. macrophylla (Bhattacharya et al., 2007). The presence of ant fauna on lac colony reduced the predator of $E$. amabilis and $P$. pulverea population by $78.66 \%$ (Kumar et al., 2007). Ant in the course of collecting and feeding honeydew secreted by lac colony destroyed the eggs of the predators. The extracted essential oils from Cymbopogon citrates (lemon grass), C. martini (Palmarosa) and C. nardus (Citronella) serve as an excellent repellents against $E$. amabilis and $P$. pulverea (Bhattacharya et al., 2008).

(vii) Prevention and control of microbial flora associated with lac insects: Application of fungicides such as Bavistin (Carbendazim 0.05\%) and Dithane M-45 (Mancozeb, $0.18 \%$ ) by dipping the brood lac before inoculation and spraying on standing crop gives significantly better yield. Significant reduction $(75 \%$ to $84 \%)$ in mortality of $2^{\text {nd }}$ instar lac nymphs/ larvae was reported by the application of different concentration of Carbendazim and Aureofungin on Kusmi strain of lac insect.

\section{Livelihood improvement}

Employments Generation: The impact of training on lac grower's employment was studied by $\mathrm{Pal}$ (2009) during the years 2003-04 and 2004-05 in the Ranchi and West Singhbhum districts of Jharkhand. He reported that the increase in employment after training of lac growers in comparison to untrained lac-growers (Table 8). He further found that the employment generation in lac cultivation had increased by about $28.0 \%$ on palas, $32.0 \%$ on ber and $17.6 \%$ on kusum for trained lacgrowers. More than $60.0 \%$ of the human labour used in lac cultivation was the family labour in all the three cases. Whereas, some lac growers do not go for engaging labour. Employment generation opportunities which were created and calculated as per field experience, market prices of produce and wage rates. As lac cultivation has very high potential for generating employment opportunity for both men and women, a work study was conducted by Jaiswal et al. (2011) and Jaiswal et al. (2013) on major lac host trees. They revealed that the lac cultivation generates an employment for 28-55 male and 17-35 female days on Palas, 39-67 male and 77-110 female days on BerRangeeni, 87 male and 58 female days from BerKusumi, 108-147 male and 85-160 female days on Kusum.

Income generation: Lac cultivation serves as a complementary and supplementary source of income for improving existing livelihood of the farmers in the states of Jharkhand, Chhattisgarh, Madhya Pradesh, Maharashtra, West Bengal, Odisha and other lac producing states of India. It is also an assured source of income during lean period of agricultural activities and providing additional source of income and cash flow to the marginal, small and large farmers, and sub-forest 
dwellers in the country. Lac cultivation is simple and required very low investment. It is eminently suited to the farmers living in the vicinity of the forests including women as it demands only their part time attention. With low cost inputs, it gives high returns which make it highly favourable with the farmers.

Income generation through lac cultivation in various host plant viz. Palas, Ber, and Kusum, maximum gross return (Rs. 9,77,600) was generated by 100 Kusum host plants. Whereas only 40 host plants of Ber-Kusumi crop have generate about Rs. $8,55,000$ gross return (Table 10). The highest net return was recorded from 100 Kususm host plants followed by 40 Ber-Kusumi plants, 100 BerRangeeni plants and 100 Palas plants. The highest output- input ratio (6.80) was found for Berkusumi crop (Jaiswal et al., 2011; 2013).

The returns from lac cultivation on different host plants under trained and untrained lac-growers condition have been depicted in Table 11. The cost of cultivation and net returns increased in the case of trained lac-growers. The cost of cultivation was increased due to utilization of more labour and broodlac. The cost of cultivation was increased by $38 \%$ in Palas, $70 \%$ in Ber and $60 \%$ in Kusum. While the increase in net return was by $67 \%, 114 \%$ and $103 \%$ for Palas, Ber and Kusum, respectively. The B: C ratio was found to be higher in the case of trained than untrained lacgrowers on all the three hosts. Regarding lac cultivation on different hosts, highest $B$ : $C$ ratio was found in kusum, followed by ber and palas (Pal et al., 2009; Pal and Yog, 2014). Comparative study of net income derived from farm activities, nonfarm activities and lac activities was conducted in Purulia district of West Bengal during 2009-10 (Mandal and Sarkhel, 2014). They revealed that the net income from lac activities contributed $54.61 \%$ at marginal farmers, $48.76 \%$ at small farmers and $55.58 \%$ at medium farmers (Table 12).

\section{Conclusion}

The Jharkhand state of India alone contributes around $60 \%$ in total lac production, whereas, Chhatisgarh stands at second and Madhya Pradesh at third in lac producing states, contributing 16 and $12 \%$, respectively. Rangeeni and kusami lac were vulnerable to both biotic and abiotic stress conditions. The temperature is the most important climatic factor (abiotic) affecting lac production in India. Changes in rainfall patterns, frequent droughts and floods, increased intensity and frequency of cold waves are the other abiotic factors affecting profoundly lac sub-sector. Among the parasites, Tachardiaephagus tachardiae and Tetrastichus purpureus are the most abundant lac associated parasites, whereas Eublemma amabilis and Pseudohypatopa pulverea were the most destructive key predators. The reported losses in lac production due to different biotic and abiotic factors may be managed and minimized through applying different control measures. Lac cultivation serves as both a complementary and supplementary source of income to the existing livelihood options for the farmers in the states of Jharkhand, Chhattisgarh, Madhya Pradesh, Maharashtra, West Bengal, Odisha and other lac producing states of India. Lac cultivation generates an employment for 16-160 man days for different lac crops. Lac cultivation produces maximum gross return of Rs. 9, 77,600 from 100 Kusum host plants, whereas the highest $(6.80) \mathrm{B}: \mathrm{C}$ ratio was recorded in Ber-kusumi crop in Ranchi, Jharkhand. Net income from lac activities contributes $54.61 \%$ at marginal farmers' field, $48.76 \%$ at small farmers' field and $55.58 \%$ at medium farmers' field. The study creates awareness among the lac growing farmers and researchers towards the different obstacles comes while rearing lac insects and their control measures for increasing lac production.

\section{ACKNOWLEDGEMENTS}

Authors would like to thank Dean, College of Agriculture, Balaghat for encouraging and providing assistance writing the article.

\section{REFERENCES}

1. Anonymous (2006). Annual Climate Summary 2006. Government of India, Ministry of Earth Sciences, India Meteorological Department, Pune, India. 1-24

2. Anonymous (2007). Annual climate summary 2007. Government of India, Ministry of Earth Sciences, India Meteorological Department, Pune, India. 1-24

3. Anonymous (2008). Annual climate summary 2008. Government of India, Ministry of Earth Sciences, India Meteorological Department, Pune, India. 1-24

4. Anonymous (2009). Annual climate summary 2009. Government of India, Ministry of Earth Sciences, India Meteorological Department, Pune, India. 1-24

5. Anonymous (2010). Annual climate summary 2010. Government of India, Ministry of Earth Sciences, India Meteorological Department, Pune, India. 1-25

6. Anonymous (2011). Annual climate summary 2011. Government of India, Ministry of Earth Sciences, India Meteorological Department, Pune, India. 1-24

7. Anonymous (2012). Annual climate summary 2012. Government of India, Ministry of Earth Sciences, India Meteorological Department, Pune, India. 1-24

8. Anonymous (2013). Annual climate summary 2013. Government of India, Ministry of Earth Sciences, India Meteorological Department, Pune, India. 1-24

9. Bhagat, M.L. and Mishra, Y.D. (2002). Abiotic Factors Affecting Lac Productivity. In: Recent Advances in Lac Culture. Kumar, K.K., R. Ramani and K.K. Sharma (Eds.). ILRI, Ranchi, India, pp 64-68.

10.Bhattacharya, A., Jaiswal, A. K., Singh, J. P., and Goel, S. C. (2008). Management of Lac Insect Predators through IPM based Biorational Approaches. In: Emerging Trends of Researches in Insect Pest Management and Environmental Safety, Goel, S.C. (Ed.). 
Vol. 1, Uttar Pradesh Zoological Society, India, pp 221-226.

11.Bhattacharya, A., Kumar, S. and Jaiswal, A. K. (2007). Evaluation of Trichogramma species for the suppression of lepidopteran insect predator, Eublemma amabilis Moore, in lac culture on Flemingia macrophylla. J. Biol. Control., 21: 267-270.

12.Bhattacharya, A., Kumar, S., Jaiswal, A. K. and Kumar, K. K. (2006). Trichogramma spp. for the management of Eublemma amabilis Moore (Lepidoptera: Noctuidae) - a predator of Indian lac insect. Entomon., 31(2): 121-124.

13.Chattopadhyay, S. (2011). Introduction to lac and lac culture. Birsa Agricultural University, Kanke, Ranchi834006 (Jharkhand). 26p.

14.Glover, P. M. (1937). Lac Cultivation in India. $2^{\text {nd }}$ Edn. Indian Lac Research Institute, Ranchi, India. $147 p$.

15.Gogoi, I. and Dutta, B. C. (2000). Seasonal abundance of cotton jassid, Amrasca Biguttula biguttula (Ishida) on Okra. J. Agric. Sci. Soc., 13: 22-26.

16.IINRG (2014). Network project on conservation of lac insect genetic resources. Namkum, Ranchi. 12p.

17.IPCC (2007). Climate Change 2007: Impacts, Adaptation and Vulnerability: Contribution of Working Group II to the Fourth Assessment Report of the Intergovernmental Panel on Climate Change. Cambridge University Press, Cambridge, UK. 976p.

18.Jaiswal, A.K., Sharma, K.K. and Kumar, K. K. (2006). Importance of lac in socio-economic life of tribals in Ranchi district (Jharkhand). New Agriculturist, 17(1,2): 133-137.

19.Jaiswal, A. K., Bhattacharya, A., Kumar, S. and Patamajhi, P. (2007). Evaluation of ethofenprox on Chrysopa madestes (Neuroptera: Chrysopidae): A serious pest of Indian lac insect, Kerria lacca (Kerr). J. Entomol. Res., 31: 113-114.

20.Jaiswal, A. K., Bhattacharya, A., Kumar, S. and Singh, J.P. (2008). Evaluation of Bacillus thuringlensis Berliner sub sp kurstaki for management of lepidopteran pests of lac insect. Entomon, 33: 65-69.

21.Jaiswal, A. K., Govind Pal, Singh, J. P. and Bharati Patel. (2011). Study of lac production growth in Jharkhand: district-wise and crop-wise analysis. Indian Forester, 137(11): 1309-1312.

22.Jaiswal, A.K. and Sharma, K.K. (2011). Lac insect, its development and life cycle. In: Sharma, K.K. and Ramani, R. (eds) Recent advances in lac culture. 22$26 \mathrm{pp}$.

23.Jaiswal, A.K., Govind Pal, Singh, J.P. and Bharati Patel. (2013). Growth analysis of lac production in Madhya Pradesh. Indian Forester, 139 (5): 448-452.

24.Khopragade, D., Thomas, M., Pachori, R., Sharma, J.L. and Shrivastava, A. (2012). Farmer participatory trial on the predator management of Lac insect $K$. lawwi (Kerr) in Anuppur District, Madhya Pradesh. Journal of Tropical Forestry, 28(1\&2): 38-45.

25.Kumar, S., Kumari, V. and Sharma, A.K. (2007). Ant fauna: A potential bio control agent in lac ecosystem. Indian J. Entomol., 69: 359-362.

26. Malhotra, C. P. (1983). Control of pests of lac insect Kerria lacca (Kerr) for easy adoption by cultivators. Indian Shellac, 1: 6-7.

27.Mandal, J.P. and Sarkhel, J. (2014). Cost of lac cultivation and its profitability in Purulia district- $A$ case study. Business Spectrum, IV (1): 1-10.

28.Meena, S. C., Sharma, K. K., Mohanasundaram, A.,
Verma, S. and Monobrullah, M. D. (2014). Insect-pest complex of Flemingia semialata Roxb - a bushy host for lac cultivation. The Bioscan, 9(4): 1375-1381.

29.Mehra, B. P. (1965). Biology of Chrysopa madestes banks (Neuroptera: Chrysopidae). Indian J. Entomol., 27: 398- 407.

30.Mehra, B. P. (1966). Biology of Chrysopa laciperda Kimmins. J. Bombay Natl. Hist. Soc., 63: 215-218.

31.Mishra, Y. D. (2002). Technology of lac cultivation on Kusum. In: Recent Advances in Lac Culture. Kumar, K.K., R. Ramani and K.K. Sharma (Eds.). ILRI, Ranchi, India. 1-290 pp.

32.Mishra, Y. D., Chaudhary, S.G., Bhattacharya, A. and Kumar, P. (1999b). Advanced broodlac production technology on Kusum. Technical Bulletin No. 1, International Livestock Research Institute (ILRI), Namkum, Ranchi, India. 1-8 pp.

33.Mishra, Y. D., Sushil, S. N., Sharma, K. K., Bhattacharya, A. and Jaiswal, A. K. (1996). Efficacy of selected organophosphorus insecticides for control of Chrysopa madestes (Neuroptera: Chrysopidae): A serious sporadic predator of Indian lac insect, Kerria lacca (Kerr). New Agriculturist, 7: 17-20.

34.Mishra, Y. D., Sushil, S.N., Bhattacharya, A. and Kumar, S., Mallick, A. and Sharma, K. K. (1999a). Intra specific variation in host plants affecting productivity of Indian lac insect, Kerria lacca (Kerr). J. NonTimber For. Prod., 6:114-117.

35.Mittler, R. (2006). Abiotic stress, the field environment and stress combination. Trends Plant Sci., 11: 15-19.

36.Mohanta J., Dey, D. G. and Mohanty, N. (2014). Studies on lac insect (Kerria lacca) for conservation of biodiversity in Similipal Biosphere Reserve, Odisha, India. Journal of Entomology and Zoology Studies, 2 (1): 1-5.

37.Murugan, M. and Uthamasamy, S. (2001). Dispersal behaviour of cotton whitefly Bemisia tabaci (genn.) under cotton based garden land agro ecosystem of Coimbatore. Madras Agric. J., 88: 1-6.

38.Narayanan, E. S. (1962). Pest of Lac in India. Indian Lac Research Institute, Ranchi, India. 90-133 pp.

39.Nicholson, J. W. (1925). Some notes on lac cultivation. Indian forester, 51(10): 483-498.

40.Pal, G. (2009). Impact of scientific lac cultivation training on lac economy: A study in Jharkhand. Agric. Econ. Res. Rev., 22: 139-143.

41.Pal, G. (2015). Study on methodology for estimation of lac production in India. International Research Journal of Agricultural Economics and Statistics, 6(1): 205-209.

42.Pal, G. and Yog, R. K. (2014). Socio-economic status of Lac growers in Korba District of Chhattisgarh. International Journal of Agricultural Sciences, 10(1): 167-171.

43.Pal, G., Bhagat, M. L. and Bhattacharya, A. (2009). Economics and resource use efficiency of Lac cultivation in Jharkhand. Indian J. For., 32: 95-98.

44.Pal, G., Jaiswal, A. K. and Bhattacharya, A. (2011). Lac statistics at a glance 2010. Technical Bulletin No. 01/2011, Indian Institute of Natural Resins and Gums, Ranchi. 1-24 pp.

45.Paul, B., Kumar, S. and Das, A. (2013). Lac cultivation and their host trees found in Bastar Forest Division. Plant Sci. Feed, 3 (1): 8-12.

46.Panickar, B. K. and Patel, J. R. (2001). Population dynamics of different species of thrips on chilli, cotton 
and pigeon pea. Indian J. Entomol., 63: 170-175.

47.Patel, K. I., Patel, J. R., Jayani, D. B., Shekh, A. M. and Patel, N. C. (1997). Effect of seasonal weather on incidence and development of major pests of okra Abelmoschus esculentus. Indian J. Agric. Sci., 67: 181-183.

48.Rahman, M. M., Ahmed, K. N., Karim, K. N. S. and Ali, M. S. (2009). Bionomics of Eublemma amabilis Moore (Lepidoptera: Noctuidae), a major predator of lac insect and its control measure. Bangladesh $\mathrm{J}$. Scient. Ind. Res., 44: 57-64.

49.Rao, G. G., Rao, S. N. and Ra, V.U.M. (2009). Trends in rainfall and temperature in rain fed India in previous century. In: Global Climate Change and Indian Agriculture: Case Studies from ICAR Network Project, Aggarwal, P. K. (Ed.). ICAR Publication, New Delhi. 71-73 pp.

50.Shah, T. H., Thomas, M. and Bhandari, R. (2014). Impact of nutrient management in Zizyphus mauritiana (Lamb.) on the survivability of lac insect and the yield of Aghani crop of Kusmi lac. Journal of Entomology and Zoology Studies, 2 (5): 160-163.

51.Shah, T. H., Thomas, M. and Bhandari, R. (2015). Lac production, constraints and management: a review. International Journal of Current Research, 7(3): 13652-13659.

52.Sharma, K. K. (2007). Lac insect-host plant interaction: implications on quantity and quality of lac. In: model training course on advanced lac production, storage and application technology for employment and income generation. Bhattacharya, A., Jaiswal, A. K., Prasad, N. and Pal, G. (Eds.). ILRI, Ranchi, India. 41-48 pp.

53.Sharma, K. K., Jaiswal, A. K. and Kumar, K. K. (2006). Role of lac culture in biodiversity conservation: issues at stake and conservation strategy. Current Science, 91(1): 894-898.

54.Sharma, K. K., Kumari, K. and Lakhanpaul, S. (2007). Super parasitism in Indian lac insect, Kerria lacca (Kerr) and its implication on fecundity and resin producing efficiency of its two strains. Entomon J., 32: 33-39.

55.Sharma, K. K., Ramani, R. and Mishra, Y.D. (1997). An additional list of the host plants of lac insects, Kerria spp. (Tachardidae: Homoptera). J. Non-Timber For. Prod., 4: 151-155.

56.Sharma, K.K. (2017). Lac insect and plant host. In: Industrial Entomology. Omkar (ed). Springer Nature, Singapore. 157-180 pp.

57.Singh, J. P., Jaiswal, A. K. and Monobrullah, M. D. (2011a). Safety evaluation of some newer pesticides against lac insect (Kerria lacca) for managing predators. Indian J. Agric. Sci., 81: 465-469.

58.Singh, J. P., Jaiswal, A. K., Monobrullah, M. D. and Bhattacharya, A. (2009). Response of some selected insecticides on neuropteran predator (Chrysopa lacciperda) of lac insect (Kerria lacca). Indian J. Agric. Sci., 79: 727-731.

59.Singh, J.P., Jaiswal, A. K., and Monobrullah, M.D. (2011b). Green lacewing (Chrysoperla zastrowi Arabica) incidence on Indian lac insect (Kerria lacca). Indian J. Agric. Sci., 81:1087-1089.

60.Shrivastava, S. C. (2007). Advanced lac production, storage and application technology for emplacement and income generation. Model training course on advanced lac production, storage and application technology for employment and income generation. Indian Lac Research Institute, Namkum, Ranchi. 64$67 p p$.

61.Thomas, M. (2010). Madhya Pradesh: current status of lac production, issues, remedial measures and support system for development. Current issues related to lac production. $35-37 \mathrm{pp}$.

62.Toda, S. and Kashio, T. (1997). Toxic effects of pesticides on the larvae of Chrysoperla carnea. Proc. Assoc. Plant Prot., 43: 101-105.

63.Yogi, R.K., Kumar Alok and Jaiswal, A.K. (2017). Lac, Plant Resins and Gums Statistics 2015: At a Glance. ICAR-Indian Institute of Natural Resins and Gums, Ranchi (Jharkhand), India. pp-1-72. 